\title{
An Evaluation of the Impact of Information and Communication Technologies: Two Case Study Examples
}

\author{
Idisemi Apulu (Corresponding author) \\ School of Technology, University of Wolverhampton \\ Wulfruna Street, Wolverhampton, WV1 1LY, United Kingdom \\ E-mail: i.apulu@wlv.ac.uk \\ Dr. Ann Latham \\ School of Technology, University of Wolverhampton \\ Wulfruna Street, Wolverhampton, WV1 1LY, United Kingdom
}

Received: March 5, $2011 \quad$ Accepted: April 18, $2011 \quad$ doi:10.5539/ibr.v4n3p3

\begin{abstract}
There is a growing requirement in recent times for stronger cost control and a demand for higher returns in businesses (Milis and Mercken, 2003). The use of Information and communication technology (ICT) to gain competitive advantage has become a key strategic issue amongst organizations in the fast globalizing environment (Kakabadse et al., 2005), as ICT plays a strategic role in the management of organizations. Rastrict and Corner (2010); Lin and Lin (2006) amongst others reveal that there is a growing support for the positive relationship between ICT and its benefits. Thus, it implies that ICT brings about organizational advantage. This paper is drawn from on-going $\mathrm{PhD}$ research and it intends to deepen our understanding on the impact of implementing ICT in organizations using two companies in Nigeria as case study examples. It further identifies the reasons behind the companies' decisions to adopt ICT and the benefits associated with the use of ICT.
\end{abstract}

Keywords: Impact, ICT, Organizations, Competitive advantage

\section{Introduction}

There is a rapid development in the use of ICT in organizations. ICT plays a crucial role in the present knowledge based economy hence, organizations tend to rely heavily on ICT solutions in order to develop and grow their businesses (Asgarkhani and Young, 2010). The revolution in the use of ICT has profound implications for economic and social development and has pervaded every aspect of human life (Shanker, 2008). The use of ICT is widespread and regarded as an essential tool for the efficient administration of any organization and in the delivery of services to clients. Schware (2003), states that ICTs are being integrated into procedures, structures, and products throughout businesses, governments, and communities. The use of ICT increases the supply of information as ICT plays a key role in information sharing and dissemination. According to Spanos et al. (2002), ICT removes distance and time constraint in accessing required information flows. ICT also reduces the cost of production as knowledge is produced, transmitted, accessed and shared at the minimum cost. There is a reduction in the degree of inefficiencies and uncertainty with the use of ICT because it enables businesses to interact more efficiently (Buhalis, 2003).

Shanker (2008) ascertains that the use of ICT in many organizations has assisted in reducing transactional cost, overcome the constraints of distance and have cut across geographic boundaries thereby assisting to improve coordination of activities within organizational boundaries. Also, Spanos et al (2003) state that buyers and sellers are able to share information and transfer goods across national borders with the use of ICT, which helps to increase access to global supply chains. ICT has also led to more transparency in organizations since it enables networking and information sharing that leads to demands for greater openness and transparency (Shanker, 2008; Kollberg and Dreyer, 2006). Jiménez-Zarco et al. (2006) further argue that ICT plays an important role in acquiring, creating and managing knowledge as it enables the diffusion of organizational data that can be crucial for effective decision making and control at all levels. Likewise, ICT helps in organizational planning and improves organizational communication and flexibility. 


\section{Literature Review}

\subsection{Information and Communication Technology}

ICT can be defined as technologies that enable recording, processing, retrieving and the transmission of information or data. Herselman and Hay (2003), describe ICT as technologies that support the communication and co-operation of "human beings and their organizations" and the "creation and exchange of knowledge. Furthermore, Yu (2010) considers ICT as a range of technologies that allow the gathering, exchange, retrieval, processing, analysis and transmission of information. In order words, ICT can be described as any tool that facilitates communication, process and transmit information and share knowledge through electronic means.

Rwashana and Williams (2006) advocate that ICT encompasses a range of electronic digital and analog devices such as radio, television, telephones (fixed and mobile), computers, electronic-based media such as digital text and audio-video recording, and the internet, but excludes the non-electronic technologies. Selwyn (2002) refers to ICT as "an umbrella term that includes computer hardware and software; digital broadcast and telecommunications technologies as well as electronic information repositories such as the World Wide Web or those found on CD-ROMs". Ssewanyana (2009) further describes ICT as a strategic tool that allows users to become more efficient and effective.

\subsection{The Impact of ICT}

Presently, the extensive use of ICT is changing the way people or companies work. Researchers (e.g. Hipp and Grupp 2005; Tidd et al., 2005 and Castellacci, 2006) refer to ICT as a very important tool for innovation in this present era. The benefits of ICT for a firm includes saving of inputs, general cost reductions, higher flexibility and improvement in product quality (Mouelhi, 2009; Majumdar et al., 2010). Bloom et al. (2009) ascertain that ICTs play a major role in networking and communication as firms use these technologies to facilitate communication among employees and reduce co-ordination costs. According to Hanna (2003), ICT enhances the production process in organizations as monitoring technologies could be used to reduce the number of supervisors required in the process. Arvanitis and Loukis (2009) also advocate that the use of ICT has direct implications for firms. ICT helps in areas such as information gathering and dissemination, inventory control and quality control.

Olugbenga (2006) argues that ICTs are being used for strategic management, communication and collaboration, customers' access, managerial decision making, data management and knowledge management since it helps to provide an effective means of organizational productivity and service delivery. According to Brynjolfsson and Hitt (2003) there is a substantial long-term productivity gain with the use of ICT in organizations. Buhalis (2003) also notes that the application of ICT in businesses causes fundamental changes that can provide powerful strategic and tactical tools for organizations if properly applied and used. This could have great impact in promoting and strengthening organizational competitiveness.

Krishnaveni and Meenakumari (2010) assert that ICT has played a major role in reducing operational inefficiency and improving decision-making in many areas of governance. Cordella (2006) emphasizes that the diffusion of ICT in the present era is associated with an increased amount of information becoming available. Furthermore, Hengst and Sol (2001) affirm that ICT enables organizations to decrease costs, increase organizational capabilities and also, assist to shape inter-organizational coordination. Therefore, the use of ICT can help to lower coordination cost and increase outsourcing in organizations. Similarly, Ramsey et al. (2003) in their report mentioned that organizations generally stand to gain from ICT in areas such as reduced transaction costs. In order words, the use of ICT could assist both individuals and companies to access large markets at low cost. In addition, Irvine and Anderson (2008) comment that the use of ICT does not only offer practical benefits for general management, but also enables companies to overcome the disadvantages of place and space.

Porter (1990) defines competitive advantage as the heart of a company's performance. It reflects a company's ability to offer consumers greater value either by means of lowering prices or by providing greater benefits and services that justifies higher prices. Alam and Noor (2009) argue that ICT offers enterprises avenues to compete on a global scale with improved efficiency and closer customer and supplier relationships. Therefore, ICT should be regarded by businesses as an important strategy to stay competitive. Similarly, Melville et al. (2004), highlight that the use of ICT brings about customer satisfaction by improving service quality thereby offering new opportunities for companies. Apulu and Latham (2010), claim that ICT enables customers to receive immediate feedbacks that allow companies to react fast to customers' demands and recognize new market niches. This entails that organizations that are able to exploit the potentials offered by ICT can handle various types of innovative processes in their businesses since ICT influences the performance of an organization in multifaceted ways. Thus, ICT can bring about change in organizations and make them more competitive, innovative and assist to increase organizational growth (Obijiofor et 
al., 2005). For these reasons, Kapurubandara and Lawson (2006) recommend that organizations need to adopt ICT in order to remain competitive in the present competitive global economy.

\section{Research Method}

Case study research is one of the most common approaches applied in the field of Information Systems (IS) (Alavi et al., 1992). Sauer (1993) asserts that research in information systems is best done by case study. Myers (1997) further argues that the case study approach is well-suited to IS research as it helps to study the use of technologies in organizations. Yin (2003) advocates that case study method provides an opportunity to study a phenomenon within its natural context. As a result, this study employs a case study research method based on two companies that have not only successfully adopted ICT, but effectively utilizes ICT in their organizational processes. The case study method was deemed appropriate since the aim of the paper is to broaden our understanding on the impact of ICT implementation in companies. Data was gathered through semi-structured interviews, review of company documents and observations. The interviews were conducted with the owner-managers and heads of IT department of both companies in order to understand their perceptions and experiences with regards to the use of ICT. Data collected during the interviews were sorted, coded and categorized into themes. There was also a review of relevant literatures relating to the subject that assisted in developing further prompting questions during the interviews.

\section{Results and Discussion}

\subsection{Company A}

Company A is a marketing company located in Lagos, Nigeria. The company has 43 employees and has its Head office in Port - Harcourt, Nigeria. The company was established 12 years ago and deals with sales and services of generators and heavy duty equipments and sometimes rentals of generators. Company A has various departments which include sales department, administration department, technical and workshop department, accounts department, with each department having a manager. The company's goal is to gain a very large share of the generator market. However, the company has many competitors that are also working hard to gain a large share of the generator market, especially in Lagos, where it is very competitive. Hence, company A decided to adopt ICT in order to have some competitive advantage.

It is part of the company's goal to achieve customers' satisfaction. There is a culture in the company that after a customer purchases a generator, at the completion of 1000 hours of the generator use, the company offers a free maintenance service, after which a service contract can be negotiated. Company A also has a culture that when a customer purchases a generator, it is delivered free of charge and the customer is given a warranty for the generator. Within one year or 1,500 hours of use, if there is any defect, the company replaces the generator for free.

\subsubsection{Use of ICT in Company A}

Company A uses an accounting package called Business Soft as well as Microsoft Office. The reason for implementing the software is primarily to become more efficient. The company believes that ICT is the technology of the day and that the world is a global village, hence as a company with many competitors, company A realized the need to use some forms of ICT such as the accounting software in its organization. The owner-manager believes that ICT will assist in the management of the company's accounts and also assist to effectively store the company's data.

Company A comments:

"In order for us to become more efficient and effective in our business operations, audit our accounts and store information properly, we had to move from manual to electronic and so we decided to start using some types of ICT such as the Business Soft accounting package. ICT has assisted us to coordinate and control our firm's operations better and it has improved record keeping in the company, especially when it comes to information regarding other companies and our customers, as we now store these information on our system unlike before, when we only had them in files". [Company A - owner-manager].

Company A affirms that the adoption of ICT has been very useful to their company especially in terms of comparing manual accounting to electronic operations. According to the head of the IT department:

"Ever since we started using the accounting package, all we need to do is to key in the right information and it gives us the right financial statement". [Company A -head of IT department].

ICT has enabled the company to have an effective accounting system with the use of the software. This now helps to produce the company's financial statements when due, hence audit reports are always completed on time. The manager stated that there are no more delays, due to the implementation of ICT in the company. 


\subsection{Company $B$}

Company B is a manufacturing company that manufactures shoes. The company is also located in Lagos, Nigeria and was established 15 years ago. It is a family owned business and presently has 57 employees. It was the owners' notion to adopt some forms of ICT in the organization. The owners' believe that ICT would bring about improved productivity and also assist in increasing sales. The company's goal is to satisfy their customers at minimum cost via the product they manufacture. As a company, they have competitors that are also in the manufacturing business. The ICT infrastructure in the company is the internet and company B also, uses Microsoft Office. The company decided to adopt the internet when one of the owners, now the manager realized that the world is going global so there was a need for advancement as an organization in order not to be left behind. Also the entire management of the company believes that people require timely and accurate information nowadays to enable them make immediate decisions. Therefore, the company decided to use some form of ICT, such as the internet to stay competitive.

\subsubsection{Use of ICT in Company B}

Company $\mathrm{B}$ uses the internet to send emails, obtain information about products and to maintain contact with customers. Irrespective of the fact that the owners decided to adopt ICT in order to make information available at all times, they also decided to implement ICT due to the stress of manual data processing which was referred to as cumbersome. The company believes that ICT enables easy analysis of data and it brings about development.

Company B comments that:

"ICT makes our work easy, it helps the company to retrieve and send information speedily. In the past, we constantly searched the shelves for files which was always time consuming but with ICT, customers' records are now stored in the computer thereby making information retrieval stress-free. Also we no longer spend time travelling to places to deliver vital documents to our business partners or spend money trying to deliver these documents via courier as we can now send documents via email with the presence of the internet". [Company B -Manager].

Company B assumes that the use of ICT in the organization has increased information availability on a daily basis. It has also improved communication within and outside the company. The head of the company's IT department states that:

"With the use of ICT, we are now able to save our customers details such as telephone numbers and email addresses by putting them in a data entry sheet. This helps us as a company to easily send information to our customers". [Company B - Head of IT department].

Having internet presence also helps the company to obtain market statistics whenever needed. Therefore, with the adoption of ICT such as the internet, Company B is able to communicate effectively and efficiently with their clients and also manage their company's data.

\section{Discussion}

The literature review and case studies have enabled the researchers to further determine the impact of ICT in businesses. Both cases mentioned that the use of ICT in their respective companies has led to a more efficient and effective way of handling their business operations since the use of ICT enables fast and accurate processing of information. Similarly, Alam and Noor (2009) confirm that ICT offers enterprises improved efficiency in business transactions. Fink and Disterer (2006) also advocate that ICT offers many potential benefits to organizations so as to make them more efficient, effective and competitive.

Company A accepts that the use of ICT has assisted in improving the company's accounting system, record keeping and has enhanced the coordination of various activities in the company. The company's major reasons for implementing ICT was to become more efficient, effective and to automate the company's records. According to Ion and Andreea (2008), organizations are able to obtain, process, accumulate and exchange information with the use ICT. Shanker (2008) also notes that the use of ICT in organizations brings about transparency and enables effective information sharing. Both companies decided to adopt ICT in order to have some form of competitive advantage. Fullanteli and Allegra (2003), states that ICT offers enterprises a wide range of possibilities for improving their competitiveness and provides mechanisms for getting access to new market opportunities. Ongori (2009) also agrees with this, stating that the use of ICT would help to create competitive advantage for businesses and also change business operations.

According to Kapurubandara and Lawson (2006), it is obvious that organizations embrace ICT in order to survive and stay abreast in the present competitive global economy. Company B revealed that a major reason for implementing ICT was due to the fact that the world is going global hence it was necessary as a company, to key 
into what was happening in order not to be left behind. Also they thought that people require timely and accurate information to enable them make accurate decisions. Therefore, using some form of ICT such as the internet has assisted them to meet up with their customers' demands. Company B further mentioned that ICT has made their job easier and has increased the company's speed in terms of sending and receiving information which has also improved communication with their customers. The use of ICT in both companies has enhanced communication between their various departments and branches. ICT has also assisted in increasing productivity and efficiency in the companies. Based on the case studies and literature review, it can be said that there is a huge impact associated with the use of ICT as it brings about competitive advantage in companies. Hence, it is recommended for organizations to implement ICT in their business operations.

\section{Conclusion}

This paper has emphasized that the implementation and effective use of ICT in organizations brings about competitive advantage. The use of ICT has a great impact on organizational performance as it helps to provide a platform for growth in many companies. In order words, ICT is known to improve organizational operations, growth and competitiveness. From the literature review and the case studies, it is certain that there are a number of advantages associated with the use of ICT. Therefore the effective use of ICT in many organizations would assist in creating several opportunities. This implies that there is a need for organizations to invest in ICT in order to set themselves apart from their competitors and also have sustainable competitive advantage.

The case studies have revealed that the investment in ICT needs only to be modest, as the availability of the internet and an accounts package greatly increases efficiency and aids competitive advantage. This study will be of benefit to entrepreneurs, policy makers, practitioners as well as researchers who are interested in ICT development since the study helps to further identify the impacts of ICT in organizations.

\section{Limitation and Further Research}

The study was limited to only two case studies therefore, to further evaluate the impact of ICT implementation in organizations, research involving more case studies would be useful. Also, further research could focus on collecting and analysing empirical data from SMEs and comparing the results with the findings of this study.

\section{References}

Alam, S. S., \& Noor, M. K. (2009). ICT Adoption in Small and Medium Enterprises: an Empirical Evidence of Service Sectors in Malaysia. International Journal of Business and Management, 2(4), 112-125.

Alavi M. \& Carlson P. (1992). A Review of MIS Research and Disciplinary Development. Journal of Management Information Systems, 8(4), 45-62.

Apulu, I., \& Latham, A. (2010). Benefits of information and communication technology in small and medium sized enterprises: a case study of a Nigerian SME. Proceedings of the $15^{\text {th }}$ Annual Conference on UK Academy for Information Systems, March 23-24, Oriel College, University of Oxford.

Arvanitis, S., \& Loukis, E. (2009). Information and communication technologies, human capital, workplace organization and labour productivity: A comparative study based on firm-level data for Greece and Switzerland. Information Economics and Policy, 21(1), 43-61.

Asgarkhani, M., \& Young, A. (2010). Industry view of ICT roles and skills in Canterbury. $1^{\text {st }}$ Annual Conference of Computing and Information Technology Research and Education, New Zealand.

Bloom, N., Garicano, L., Sadun, R., \& Reenen, J. (2009). The distinct effects of information technology and communication technology on firm organization

NBER Working Paper Series, Working Paper 14975, National Bureau of Economic Research. [online] Available: http://www.stanford.edu/ nbloom/w14975.pdf (December 14, 2010).

Brynjolfsson, E., \& Hitt, L. (2003). Computing Productivity: Firm-Level Evidence. Review of Economics and Statistics, 85, 793-808.

Buhalis, D. (2003). eAirlines: strategic and tactical use of ICTs in the airline industry Information and Management, 41, 805-825.

Castellacci, F. (2006). Innovation, diffusion and catching up in the fifth long wave. Futures, 38(7) 841-863.

Cordella, A. (2006). Transaction costs and information systems: does IT add up? Journal of Information Technology, 21(3), 195-202(8). 
Fink, D., \& Disterer, G. (2006). International case studies: to what extent is ICT infused into the operations of SMEs. Journal of Enterprise Information, 19, 608-624.

Fulantelli, G., \& Allegra, M. (2003). Small company attitude towards ICT based solutions: Some key-elements to improve it. Educational Technology and Society, 6, 1. [online] Available: http://www.ifets.info/journals/6_1/fulantelli.html (August 18, 2010).

Hanna, N. (2003). Why National Strategies are needed for ICT-enabled Development. Information Systems Group (ISG) Staff Working Paper, No. 3, June 2003.

Hengst, M., \& Sol, H. G. (2001). The impact of information and communication technology on interorganizational coordination: Guidelines from theory. Informing Science, Special Series on Information Exchange in Electronic Markets, 4, 3, 2001.

Herselman, M. E., \& Hay, H. R. (2003). Challenges Posed by Information and Communication Technologies (ICT) for South African Higher Education Institutions. Informing Science, 931-943.

Hipp, C., \& Grupp, H. (2005). Innovation in the service sector: the demand for service specific innovation measurement concepts and typologies. Research Policy, 34, 517-535.

Ion, P., \& Andreea, Z. (2008) Use of ICT in SMEs management within the sector of services. [online] Available: http://steconomice.uoradea.ro/anale/volume/2008/v4-management-marketing/085.pdf (October 5, 2010).

Irvine, W. \& Anderson, A. R. (2008). ICT (information communication technology), peripherality and smaller hospitality businesses in Scotland. International Journal of Entrepreneurial Behaviour \& Research, 14(4), 200 218.

Jiménez-Zarco, A. I., Martínez-Ruiz, M. P., \& Llamas-Alonso, M. R. (2006). Analysis of ICTs Opportunities on Firm's Success: An Innovation Process.Problems and Perspectives in Management, 4(4), 84-94.

Kakabadse, N. K., Kakabadse, A., \& Kouzmin, A. (2005). After the Re-Engineering: Rehabilitating the ICT Factor in Strategic Organizational Change through Outsourcing. Problems and Perspectives in Management, 1(2005), $55-71$.

Kapurubandara, M., \& Lawson, R. (2006). Barriers to Adopting ICT and e-commerce with SMEs in developing countries: an Exploratory study in Sri Lanka, University of Western Sydney, Australia. [online] Available: http://www.collecter.org/archives/2006_December/07.pdf (December 10, 2010).

Kollberg, M., \& Dreyer, H. (2006). Exploring the impact of ICT on integration in supply chain control: a research model. Department of Production and Quality Engineering, Norwegian University of Science and Technology, Norway.

Krishnaveni, R., \& Meenakumari, J. (2010) Usage of ICT for Information Administration in Higher education Institutions - A study. International Journal of Environmental Science and Development, 1(3), 282-286.

Ramsey, E., Ibbotson, P., Bell, J. \& Gray, B. (2003). E-opportunities of service sector SMEs: an Irish cross-border study. Journal of Small Business and Enterprise Development, 10, 3, 250-64.

Lin, W. T. \& Lin, H. J. (2006). International productivity paradox of IT in commercial banking: A cost efficiency analysis. The Business Review, Cambridge, 5(1), 246-252.

Majumdar, S. K. Carare, O., \& Chang, H. (2010). Broadband adoption and firm productivity: evaluating the benefits of general purpose technology. Industrial and Corporate Change, 19(3), 641-674.

Melville, N., Kraemer, K. L., \& Gurbaxani, V. (2004). Information technology and organizational performance: an integrative model of IT business value, MIS Quarterly, 28 (22), 283-322.

Milis, K., \& Mercken, R. (2003). The use of the balanced scorecard for the evaluation of Information and Communication Technology projects. International Journal of Project Management, 22(2), 87-97.

Mouelhi, R. B. (2009). Impact of the adoption of information and communication technologies on firm efficiency in the Tunisian manufacturing sector. Economic Modelling, 26 (2009) 961-967.

Myers, M. (1997). Interpretive research in information systems, in J. Mingers and F. Stowell (eds.), Information systems: An emerging discipline, McGraw Hill, London, 239-266.

Obijiofor, L., Inayatullah, S., \& Stevenson, T. (2005). Impact of new information and communication technologies (ICTs) on the socio-economic and educational development of Africa and the Asia-Pacific region. Paper presented at the 3rd working conference on Information and Communications Technology solutions for government 
operations, e-government and national development, an African Regional WSIS PrepCom Pre-Event, Accra International Conference Centre, Accra, Ghana, 27-28 January 2005.

Olugbenga, F. I. (2006). Strategic Application of Information and Communication Technology for Effective Service Delivery in an organisation. $6^{\text {th }}$ Global on Business and Economics, October 15-17, 2006 GUTMAN Business Center, USA.

Ongori, H. (2009). Role of information communication technologies adoption in SMES: evidence from Botswana. Research Journal of information technology, 1(2), 79-85.

Porter, M. E. (1990). The competitive advantage of nations. London: Macmillan.

Rastrick, K. \& Corner, J. (2010). Understanding ICT Based Advantages: A Techno Savvy Case Study. Interdisciplinary Journal of Information, Knowledge, and Management, 5, 2010.

Rwashana, A. S., \& Williams, D. W. (2008). Enhancing Immunization Healthcare Delivery through the Use of Information Communication Technologies. International Journal of Education and Development Using ICT, 4(2), 144-156.

Sauer, C. (1993). Why Information Systems Fail: A case Study Approach. Henley-on-Thames: Alfred Wailer.

Schware, R. (2003). Information and communications technology (ICT) agencies: functions, structures, and best operational practices. info, 5(3), $3-7$.

Selwyn, N. (2002). Defining the digital divide: developing a theoretical understanding of inequalities in the information age. Cardiff School of Social Sciences Occasional Paper, 49. School of Social Sciences, Cardiff University, Cardiff. [online] Available: www.cf.ac.uk/socsi/ict/definingdigitaldivide.pdf (March 3, 2011).

Shanker, D. (2008). ICT and Tourism: Challenges and Opportunities. Conference on Tourism in India - Challenges Ahead, 15-17 May 2008, IIML. [online] Available: http://dspace.iimk.ac.in/bitstream/2259/536/1/50-58.pdf (March 3, 2011).

Spanos, Y. E., Prastacos, G. P., \& Poulymenakou, A. (2002). The relationship between information and communication technologies adoption and management. Information and Management, 39, 2002, 659-675.

Ssewanyana, J. K. (2009). ICT Usage in Microfinance Institutions in Uganda. The African Journal of Information Systems (AJIS), 1(3), 5-28.

Tidd, J., Bessant, J., \& Pavitt, K. (2005). Managing Innovation: Integrating Technological, Market and Organizational Change, 3rd Edition. Wiley: West Sussex

Yin, R. K. (2003). Case Study Research: Design and Methods. $3^{\text {rd }}$ Edition, Applied Social Science Method Series. Vol. 5. Sage Publications, Thousand Oaks, CA.

Yu, E. (2010). Information and communications technology in food assistance. [online] Available: http://home.wfp.org/stellent/groups/public/documents/newsroom/wfp225972.pdf (January 15, 2011). 